\title{
Role of Azotobacter sp. Isolates as a Plant Growth Promoting Agent and their Antagonistic Potentiality against Soil Borne Pathogen (Rhizoctonia solani) under in vitro Condition
}

\author{
R. Dey ${ }^{1 *}$, K. Sarkar², S. Dutta ${ }^{2}$, S. Murmu ${ }^{2}$ and N. Mandal ${ }^{1}$ \\ ${ }^{1}$ Department of Agricultural Biotechnology, ${ }^{2}$ Department of Plant Pathology, Bidhan Chandra \\ Krishi Viswavidyalaya, Mohanpur, Nadia-741252, West Bengal, India \\ *Corresponding author
}

\section{Keywords}

Azotobacter sp, Bio fertilizer, Chemical fertilizer, Chilli, Rhizotonia solani.

Article Info

Accepted:

20 September 2017 Available Online: 10 November 2017

\section{A B S T R A C T}

The overdependence of chemical fertilizers in agriculture leads to decrease the fertility of soil and increase the chemical pollution. Thus, it is essential to adopt a new technology which is eco-friendly, cost-effective and reliable. Biofertilizer (Azotobacter, Azospirillum, etc) have been identified as an alternative to chemical fertilizer to increase soil fertility and crop production in sustainable farming. Therefore the present experiment with different isolates of Azotobacter sp. was carried out to find out effective isolate for plant growth promoting activities and biological control. In case of in vitro screening for plant growth promoting efficacy, it was found that chilli seeds bacterized with AZT8 exhibited the highest per cent seed germination (98\%) which was followed by AZT6 (86 \%) and AZT4 $(81 \%)$. Root length $(4.18 \mathrm{~cm})$ and shoot length of chilli seedlings $(6.5 \mathrm{~cm})$ were found maximum for the isolate AZT8. The calculated vigour index based on germination percentage, root length and shoot length was also recorded maximum for the isolate AZT8 (1105.445) followed by AZT6 (937.4) and AZT4 (805.95). In case of in vitro antagonistic potentiality test, AZT3 was found the most active isolate against Rhizoctonia solani giving an inhibition zone of $1.1 \mathrm{~cm}$ and also $72.2 \%$ growth inhibition. Another isolate showing better result, was AZT4, exhibiting zone of inhibition of $0.7 \mathrm{~cm}$ and mycelia inhibition of $61.1 \%$. Therefore it may be concluded from the present experiment that AZT8 as plant growth promoting activities and AZT3 as bio control agent can be used in West Bengal.

\section{Introduction}

Agricultural production has increased in developing countries due to use of highyielding varieties and enhanced consumption of high analysis chemical fertilizers after the era of green revolution. But the excessive use of chemical fertilizers has generated several environmental problems including the decreasing of soil fertility, greenhouse effect, ozone layer depletion and acidification of water. Therefore bio fertilizer is adopted as an alternative to chemical fertilizer to increase soil fertility and crop production in sustainable farming. For the last one decade, biofertilizers are used extensively as an ecofriendly approach to minimize the use of chemical fertilizers, improve soil fertility status and for enhancement of crop production by their biological activity in the rhizosphere. Biofertilizers are mainly the nitrogen fixing, phosphate solubilizing and 
plant growth-promoting microorganisms. They are Azotobacter, Azospirillum, blue green algae, Azolla, P-solubilizing microorganisms, mycorrhizae and sinorhizobium (Selvakumar et al., 2009).They significantly contribute to nitrogen fixation accounting for about $65 \%$ of the total annual $\mathrm{N}$ fixation to sustain life on earth (Newton, 1996). Amongst them, Azotobacter strains play a key role in harnessing the atmospheric nitrogen through its fixation in the roots. They have been also reported to improve fertility condition of the soil. Aerobic bacteria belonging to the genus Azotobacter represent a diverse group of free living diazotrophic (with the ability to use $\mathrm{N}_{2}$ as the sole nitrogen source) microorganisms commonly occurring in soil. In Indian soils, the population of Azotobacter is not more than $10^{5} / \mathrm{gram}$ of soil. The population of Azotobacter is mostly influenced by other microorganisms and soil biotic / abiotic factors. Azotobacter also produces some substances, thereby antagonises plant pathogens such as Alterneria, Fusarium and Helminthosporium etc. Hence, Azotobacter also acts as a biological control agent for management of different plant diseases. Azotobacter isolated from rhizosphere of certain plants was adopted to survive in the root zone of different plants such as rice, wheat, sugarcane, tea, maize, turmeric, vegetables, fruits, flowers and forest trees. They not only fix atmospheric nitrogen but also provide nitrogen compounds, growth promoting substance during process of nitrogen fixation. The beneficial effects of Azotobacter are not only due to its ability to fix atmospheric nitrogen, but also to secrete growth substances and antifungal antibiotics, which improve plant stands in inoculated fields by inhibition root pathogens. In fact, Azotobacterhas beneficial effects on plant yields, due to their ability of fixing nitrogen (Tejera et al., 2005), solubilizing phosphates (Hayat et al., 2010 and Farajzadeh et al.,
2012) and to the microbial secretion of stimulating phytohormones, like gibberellins, auxins and cytokinins (Hayat et al., 2010; Farajzadeh et al., 2012). Azotobacteralso produces antifungal antibiotics i.e. fungistatic substances with a broad active spectrum and inhibits the growth of Fusarium, Aspergillus, Helminthosporium, Alterneria, Cephalosporium, Rhizoctonia and Sclerotium rolfsii. Therefore the present experiment was carried out with the following objectives to find out the effective isolate of Azotobacter sp. as a plant growth promoting (PGP) agent as well as bio control agent from in vitro screening and antagonistic activity in West Bengal.

\section{Materials and Methods}

Roving survey was conducted in wheat fields in different districts of West Bengal including Jalpaiguri, Nadia, Hooghly, Murshidabad situated at different agro-ecological sub regions of West Bengal (AESR). Rhizospheric soils were collected in sterile polythene bags using a sterile soil digger to a depth of $20 \mathrm{~cm}$ of 3 of each of the five subplots of a field. Each soil sample of a field was mixed thoroughly in situ to prepare composite sample. All aseptic measures were taken during collection of samples to avoid contamination. Each composite sample was brought to the laboratory and subdivided into two parts of $200 \mathrm{~g}$ each, one for enumeration of bacterial population, another for nematode population and rest for physico-chemical property analysis. The samples were either undergone to instant biological analysis or dried at room temperature and sieved through a 50 mesh sieve and undergone to physicochemical property analysis using standard methods (Jackson, 1973 and Subbiah and Asija, 1956). For in vitro screening of bacterial isolates for their plant growth promoting (PGP) activities, the method is followed as described by (Shende et al., 1977) and (Elliot and Lynch,1984) with few 
modifications. Seeds were surface sterilized with $0.1 \% \mathrm{HgCl}_{2}$ for 1 minute followed by successive washing with sterile water and the water was decanted. Seeds were then added to cultures grown in liquid medium for 48 hours containing $10^{6}$ cells $/ \mathrm{ml}$. After 10 minutes the medium was decanted and $0.8 \%$ sterile water agar was poured into the Petri plates and then seeds were kept on soft agar plates and left for incubation at $30^{\circ} \mathrm{C}$ for 5-6 days. Three replicates were kept for each treatment. Seeds treated with sterilized water alone were placed on control plates. After 6 days, germination percentage, root length and shoot length were recorded.

The antagonistic effects of the Azotobacter sp. isolates were observed against Rhizoctonia solani by dual culture technique. The Petri plates are poured with $20 \mathrm{ml}$ PDA (without antibiotic) and the fresh bacterial loopful culture was streaked linearly leaving $1 \mathrm{~cm}$ from the margin. The pathogens are placed as $4 \mathrm{~mm}$ disc from the 3 days old culture at the centre of each Petri plate and plates were incubated at $28^{0} \mathrm{C}$ for 3 days. The distance between the fungal growth and the bacterial colonies was recorded.

\section{Results and Discussion}

Result of this experiment for selection of effective isolate from in vitro screening and antagonistic potentiality test of Azotobacter sp. isolates as plant growth promoting agent as well as bio control agent is presented here.

\section{In vitro plant growth promoting efficacy of the native Azotobacter isolates}

Chilli seeds were treated with Azotobacter isolates and after six days of seed bacterization, the germination percentage, root length and shoot length of seedlings were monitored. Analysis of the observed data revealed that chilli expressed the best performance in plant growth promoting activity associated with seed germinability, root length and shoot length as well as vigour index in all treatments over check. Among the ten bacterial isolates, the isolate AZT8 was found to be best plant growth promoter compared to other rhizospheric bacteria. From the data in the Table 1, it was found that seeds bacterized with AZT8 exhibited the highest per cent seed germination (98\%) in chilli, which was followed by AZT6 and AZT4. Root length and shoot length of chilli seedlings were found maximum for the isolate AZT8.

The calculated vigour index based on germination percentage, root length and shoot length was also recorded maximum for the isolate AZT8 (1105.44) followed by AZT6 (937.40) andAZT4 (805.95) (Table 1 and Fig. 1). Similar observation was also recorded by (Soleimanzadeh et al., 2010) who reported that Azotobacter when applied to seeds which improved seed germination to a considerable extent. The Azotobacter isolates were able to dissolve inorganic and organic phosphate compounds (Farajzadeh et al., 2012). Azotobacter has significant role in plant growth promotion including production of growth regulators, protection from root pathogens, and modification of nutrient uptake by the plant (Tchan, 1988).

In vitro antagonistic potentiality of the native putative Azotobacter isolates against soil borne pathogen Rhizoctonia solani

Perusal of the data in Table 2 indicated that two Azotobacter isolates showed antagonistic effect against Rhizoctonia solani under in vitro condition and inhibited the vegetative growth of the fungus at varied level. 
Table.1 In vitro plant growth promoting efficacy of the native putative Azotobacter sp. isolates

\begin{tabular}{|c|c|c|c|c|c|c|}
\hline $\begin{array}{l}\text { Sl. } \\
\text { No. }\end{array}$ & $\begin{array}{c}\text { Isolate } \\
\text { No. }\end{array}$ & $\begin{array}{l}\text { Percentage } \\
\text { seed } \\
\text { germination }\end{array}$ & $\begin{array}{c}\text { Root } \\
\text { length }(\mathrm{cm})\end{array}$ & $\begin{array}{c}\text { Shoot } \\
\text { length }(\mathrm{cm})\end{array}$ & $\begin{array}{l}\text { Vigor } \\
\text { Index }\end{array}$ & $\begin{array}{c}\text { Avg. } \\
\text { Fresh } \\
\text { wt. (mg) }\end{array}$ \\
\hline 1 & AZT 1 & $65(53.7)$ & $3.60^{\mathrm{d}}$ & $5.16^{\mathrm{cd}}$ & 569.40 & 28.18 \\
\hline 2 & AZT 2 & $65(53.7)$ & $4.12^{\mathrm{c}}$ & $6.22^{\mathrm{a}}$ & 672.10 & 28.58 \\
\hline 3 & AZT 3 & $72(58.1)$ & $4.24^{\mathrm{bc}}$ & $5.48^{\mathbf{b}}$ & 699.84 & 31.30 \\
\hline 4 & AZT 4 & $81(64.2)$ & $4.55^{\mathrm{abc}}$ & $5.40^{\mathbf{b c}}$ & 805.95 & 32.58 \\
\hline 5 & AZT 5 & $64(53.1)$ & $3.32^{\mathrm{d}}$ & $4.78^{\mathrm{e}}$ & 518.40 & 21.16 \\
\hline 6 & AZT 6 & $86(68.0)$ & $4.66^{\mathbf{a b}}$ & $6.24^{\mathrm{a}}$ & 937.40 & 32.72 \\
\hline 7 & AZT 7 & $74(59.3)$ & $4.34^{\text {abc }}$ & $4.88 \mathrm{~d}^{\mathrm{e}}$ & 682.28 & 29.36 \\
\hline 8 & AZT 8 & 98(81.9) & $4.78^{\mathrm{a}}$ & $6.50^{\mathrm{a}}$ & 1105.44 & 33.33 \\
\hline 9 & AZT 9 & $76(60.7)$ & $4.52^{\mathrm{abc}}$ & $5.40^{\mathbf{b c}}$ & 753.92 & 32.00 \\
\hline 10 & AZT 10 & $64(53.1)$ & $3.52^{\mathrm{d}}$ & $4.14^{\mathrm{f}}$ & 490.24 & 20.75 \\
\hline 11 & Control & 62(51.9) & $2.36^{\mathrm{e}}$ & $3.88^{f}$ & 386.88 & 12.71 \\
\hline 12 & SEM \pm & 1.00 & 0.14 & 0.10 & & \\
\hline 13 & $\mathrm{CD}$ & 2.95 & 0.40 & 0.29 & & \\
\hline
\end{tabular}

[Values are mean of three replications. Figures in parentheses are angular transformed values. A common letter means they are not significantly different $(\mathrm{p}=0.05)$ by DMRT.]

Table.2 In vitro antagonistic potentiality of the native putative Azotobacter isolates against soil borne pathogen Rhizoctonia solani

\begin{tabular}{|c|c|c|c|}
\hline Sl. No. & Isolate No. & \% Inhibition & $\begin{array}{c}\text { Zone of } \\
\text { inhibition(cm) }\end{array}$ \\
\hline 1 & AZT 1 & $2.2(8.6)^{\mathbf{i}}$ & 0 \\
\hline 2 & AZT 2 & $13.3(21.4)^{\mathbf{g}}$ & 0 \\
\hline 3 & AZT 3 & $\mathbf{7 2 . 2 ( 5 8 . 2 ) ^ { \mathbf { a } }}$ & $\mathbf{1 . 1}$ \\
\hline 4 & AZT 4 & $61.1(51.4)^{\mathbf{b}}$ & 0.7 \\
\hline 5 & AZT 5 & $27.8(31.8)^{\mathbf{e}}$ & 0 \\
\hline 6 & AZT 6 & $5.6(13.6)^{\mathbf{h}}$ & 0 \\
\hline 7 & AZT 7 & $0.0(0.0)^{\mathbf{j}}$ & 0 \\
\hline 8 & AZT 8 & $22.2(28.1) \mathbf{f}$ & 0 \\
\hline 9 & AZT 9 & $57.8(49.5)^{\mathbf{c}}$ & 0 \\
\hline 10 & AZT 10 & $53.3(46.9)^{\mathbf{d}}$ & 0 \\
\hline 11 & SEM \pm & $\mathbf{0 . 3 5}$ & \\
\hline 12 & CD & $\mathbf{1 . 0 5}$ & \\
\hline
\end{tabular}


Fig.1 In vitro plant growth promoting potentiality of the native putative Azotobacter sp. isolates
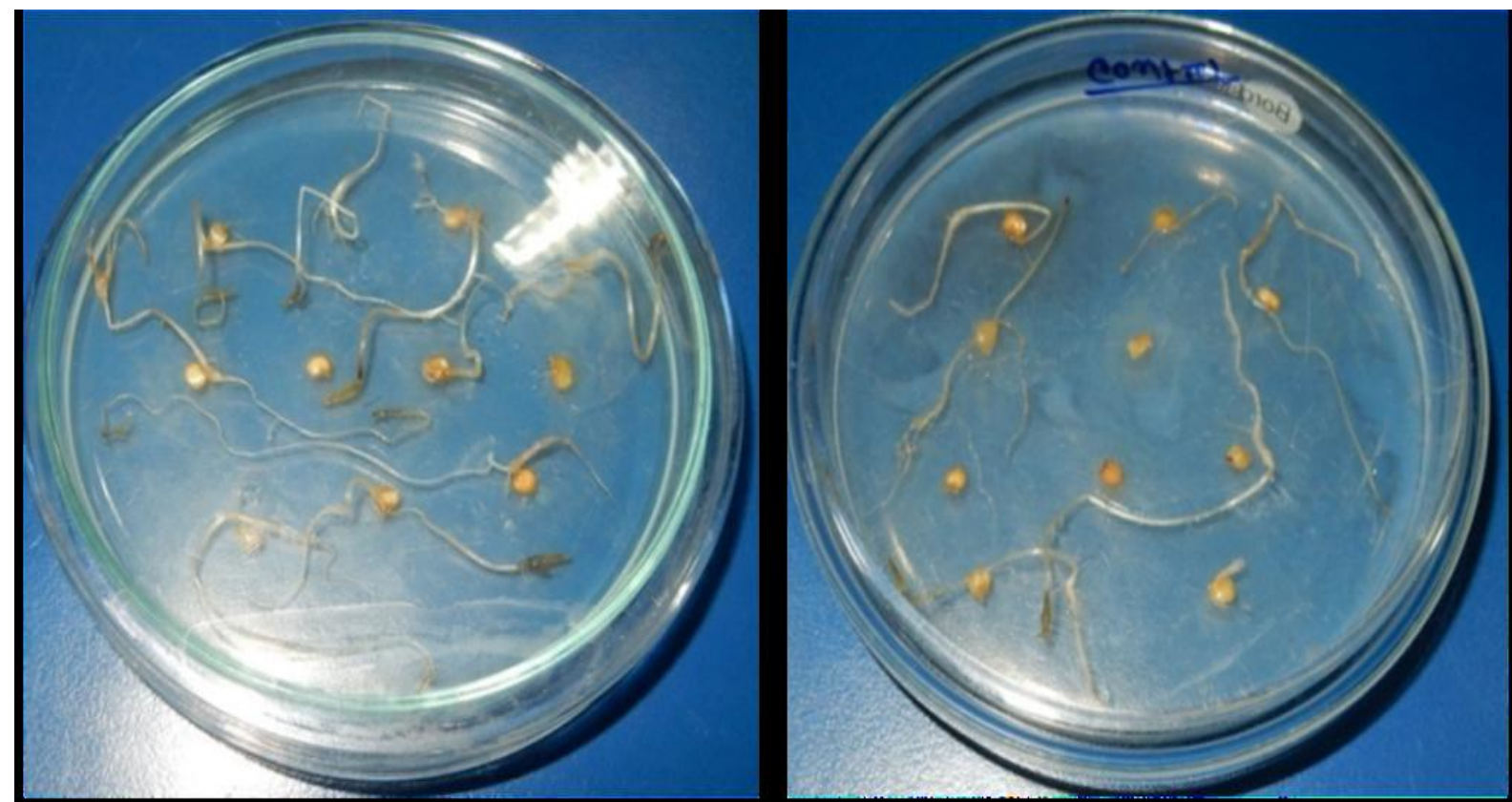

Chilli seed treated with isolate AZT 8

Control (Untreated)

Fig.2a, 2b In vitro antagonistic efficacy of the soil native putative Azotobacter isolates against soil borne pathogen Rhizoctonia solani

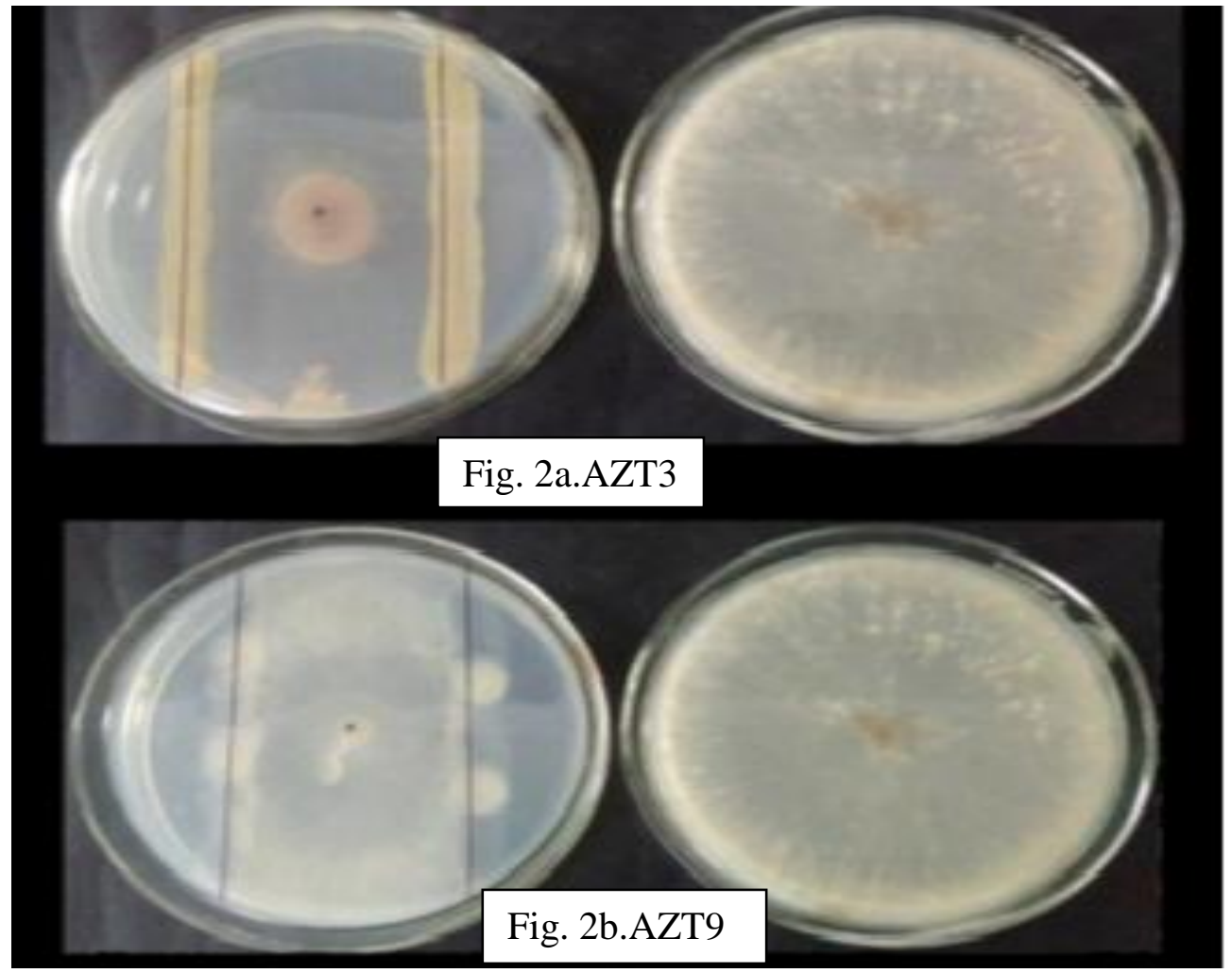


Fig.3 In vitro percent inhibition of mycelial growth of soil borne pathogen $R$. solani and vigor index of chili seedlings by different native Azotobacter isolates

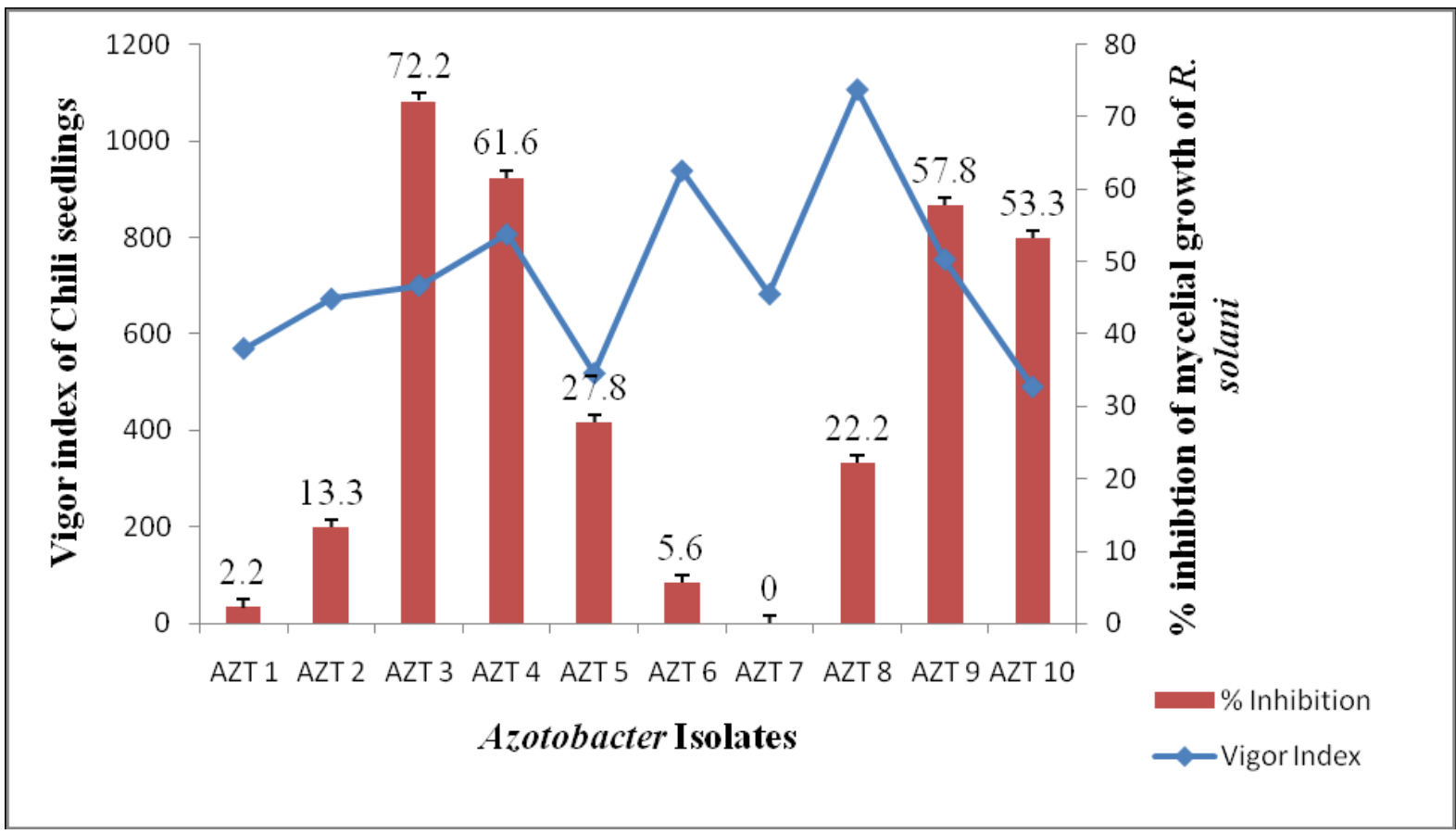

Among all the isolates, AZT3 was found to be the most active isolate giving an inhibition zone of $1.1 \mathrm{~cm}$ and also $72.2 \%$ growth inhibition (Table 2, Figure 2 and 3). Another isolate showing better result, was AZT4, exhibiting zone of inhibition of $0.7 \mathrm{~cm}$ and mycelia inhibition of $61.1 \%$. Similar observation was also reported by (Mishustin and Shilnikova, 1969), indicating that Azotobacter can produce an antifungal antibiotics which inhibits Rhizoctonia solani growth. Azotobacter sp. can also produce antifungal compounds to fight against many plant pathogens (Jen-Hshuan, 2006).

In this experiment it was found that chilli seeds inoculated with AZT8 exhibited the highest per cent seed germination (98\%). Root length and shoot length of chilli seedlings were also found maximum for the isolate AZT8 and AZT3 was found to be the most active isolate giving highest growth inhibition (72.2\%) of Rhizoctonia solani than other isolate. Therefore it may be concluded that AZT8 as plant growth promoting and AZT3 as bio control agent can be used in West Bengal.

\section{References}

Elliott, L.F. and Lynch, J.M., 1984. Pseudomonads as a factor in the growth of winter wheat (Triticum aestivum L.).Soil Biol. Biochem.16: 69-71.

Farajzadeh, D., Yakhchali, B., Aliasgharzad, N., Sokhandan-Bashir, N. and Farajzadeh, M. 2012.Plant growth promoting characterization of indigenous Azotobacteria Isolated from Soils in Iran. Curr Microbiol. 64:397403.

Hayat, R., Ali, S., Amara, U., Khalid, R. and Ahmed, I. 2010. Soil beneficial bacteria and their role in plant growth promotion: a review. Ann Microbiol. 60: 579-598.

Jackson, M.L. 1973. Soil Chemical Analysis. Prentice Hall of India Private Limited, 
New Delhi, 30: 106-109.

Jen-Hshuan, C. 2006.The combined use of chemical and organic fertilizers and/or biofertilizer for crop growth and soil fertility. International workshop on Sustained Management of the Soil Rhizosphere System for Efficient Crop Production and Fertilizer Use. 20:1-10.

Mishustin, E.N. and Shilnikova, V.K.1969. Free - living nitrogen fixing bacteria of the genus Azotobacter, In soil Biology, Reviews of Research, UNESCO Publication. Paris. 82-109

Newton, W.E. 1996.Kish-Othmer Encyclopedia of Chemical Technology (EdsJohn Wiley and Sons) New York.172-204.

Selvakumar, G., Lenin, M., Thamizhiniyan, P. and Ravimycin, T. 2009. Response of biofertilizers on the growth and yield of blackgram (Vigna mungo L.). Recent Research in Science and Technology. 1(4): 169-175.

Shende, S.T., Apte, R.G. and Singh, T. 1977.
Influence of Azotobacter on germination of rice and cotton seed. Curr Sci.46:675

Soleimanzadeh, H., Habibi, D., Ardakani, M.R., Paknejad, F., Rejali, F. and American Eurasian, J. 2010.Plant Growth Promotional Effect of Azotobacter chroococcum. AgriEnv Sci. 7(3): 265-268.

Subbiah, B.V. and Asija, G.L. 1956. A rapid procedure for estimation of available nitrogen in soils. CurrSci, 25: 259-260.

Tchan, Y.T. 1988. Some aspects of nonrhizobial diazotrophs: Their past and their future. In Microbiology in Action (Eds. Murrell WG and Kennedy IR) Research Studies Press/Wiley, Chichester, UK.193-207.

Tejera, N., Lluch, C., Martinez-Toledo, M.V., Gonzalez-Lopez, J. 2005.Isolation and characterization of Azotobacter and Azospirillum strains from the sugarcane rhizosphere. Plant Soil.270:223-232.

\section{How to cite this article:}

Dey, R., K. Sarkar, S. Dutta, S. Murmu and Mandal, N. 2017. Role of Azotobacter sp. Isolates as a Plant Growth Promoting Agent and their Antagonistic Potentiality against Soil Borne Pathogen (Rhizoctonia solani) under in vitro Condition. Int.J.Curr.Microbiol.App.Sci. 6(11): 2830-2836. doi: https://doi.org/10.20546/ijcmas.2017.611.334 